JFTH, Vol. 13, Issue 1, (2016)

ISSN: 2314-7024

\title{
Exploring the Role of Human Resource Management Practices TO RETAIN RESORTS' EMPLOYEES
}

\author{
Rania Hafez Ghareeb \\ Lecturer, Hotel Studies Department \\ Faculty of Tourism and Hotels, University of Sadat City \\ Tamer Mohamed Amer \\ Lecturer, Hotel Studies Department \\ Faculty of Tourism and Hotels, University of Sadat City
}

\begin{abstract}
The aim of this study is to explore the relationship between human resource management practices (HRMPs) implemented at five-star resorts and employee job satisfaction, and measuring its effectiveness in retaining employees. These practices include: training \& development, rewards \& benefits, personal recognition, internal communication system, performance appraisal, and employee empowerment. Data were collected by developed questionnaire. Originally, 300 questionnaire forms were distributed among employees who are working in different departments of five-star resort hotels located in Hurghada and Sharm El-Sheikh. Only 214 questionnaires were returned giving a response rate of 71.3\%. Data were statistically analyzed by using Pearson correlation coefficient and regression analysis. It is founded that all items of HRMPs are positively related to better employees' satisfaction and retention. Furthermore, three human HRMPs: Training \& development, Performance appraisal, and Rewards \& benefits are contributing strongly (adjusted $R 2=0.696$ ) in enhancing retention of resorts' employees than the other three HRM practices. It is concluding that the ability of resort hotels to retain its employees could be elevated by adapting these practices.
\end{abstract}

Keywords: Human Resource Management Practices; Employees; Retention; Satisfaction; Resorts.

\section{Introduction}

Employees are considered an important asset for any organization and a significant reason for its success. Thus, firms are interested in their human resources. This issue is important in the case of service industry (Fan et al., 2011)

Hospitality industry is characterized by its need to intensive labor. It requires various employees with requiring human various skill levels (Raybould \& Yam, 2011). In spite of its dependence on employees, high turnover rates and related costs and low retention of skilled employees important are matters that pervaded the hospitality industry (Fu et al., 2012; Kay et al., 2009). Turnover rates in hospitality are much higher than in other industries. They range from 200 to $300 \%$ per year (Woods et al., 2006; Kumar et al., 2013).Tracey and Hinkin (2000) and Birdir (2002) assured that high staff 
turnover rates in the hospitality industry are not restricted to a specific country but are a worldwide phenomenon.

Resort hotels are one from the most operations have the highest turnover rates in the service industry. So, resort hotel should give a priority to this issue and endeavor to retain their employees. By establishing strong and clear human resources policies which aim to retain employees, hotels can save time and money, improve profitability and gain a competitive advantage (Enz, 2001)

\section{Review of literature}

\section{Employee Turnover}

Yang (2010) described turnover as the suspension of an individual' s job in a particular company. Turnover is divided to: voluntary turnover and involuntary turnover ( $\mathrm{Fu}$ et al., 2012). Voluntary turnover occurs when an employee leaves his job by his will. On the other hand, involuntary turnover means that a hotel ends the working relationship with its employees (Woods et al., 2006). Thus, the voluntary turnover should be a priority for hotel managers.

\section{Costs of turnover}

High staff turnover can be resulted in greater costs for the hotels (Kumar et al., 2013). The turnover cost for an employee may be estimated at one to two times the salary of the employee (Tracey \& Hinkin, 2008). Lashely (2001) divide the costs of staff turnover into: leaving costs, replacement costs, transition and indirect or hidden costs.

Leaving costs mean all the payments which are given to the employee when he leaves the hotel (Tracey \& Hinkin, 2000). Replacement costs comprise the recruitment costs, advertising costs, interviewing and selecting costs (Fu et al., 2012; Ratna \& Chawla, 2012).Transition costs are training costs (Fan et al., 2011; Kuria et al., 2012). Indirect or hidden costs mean the costs that resulted from reducing service quality, negative impact on remaining staff, lower productivity, profitability and competitiveness (Wagar \& Rondeau, 2006; Kay et al., 2009).

\section{Turnover reasons}

Fu et al. (2012) and Helalat et al. (2014) determine the major factors which lead to leaving an organization into five human resources categories: inappropriate recruiting process, inappropriate work placement, dissatisfaction with salary, benefits and job opportunities, inappropriate management of company staff and job stress.

Researchers specify the major causes for turnover in hospitality industry as poor supervision with little responsibilities and authority, ineffective communication, the relationship with management and co-workers, lack of clear definition of responsibilities and limited career opportunities (Costen \& Salazar, 2011; Woods et al., 2006; Blomme et al., 2010).

All the above causes can be categorized under the avoidable causes of turnover as Kumar et al. (2013) divided causes of turnover into avoidable and unavoidable. Avoidable staff turnover is due to the dissatisfaction of employees with wages and the relationship with management, poor human resources management practices, lack of career development, and feeling unrecognized.

Unavoidable staff turnover occurs as a result of illness, death, marriage, work-family conflict, pregnancy (Kumar et al., 2013). 


\section{Bad effects of employees' turnover}

An increase in employee turnover has great negative effects on the hotel performance as it can decrease organizational performance as a whole and lower service standards (Rathnaweera, 2010) as a new employee will not be conversant with the new work environment (Fu et al., 2012; Fan et al., 2011; Yang, 2010). Moreover, high turnover could affect on hotel's sustainability (James \& Mathew, 2012).

\section{Human Resources Practices to Retain Employees}

Human resource practices are defined as " a set of distinct but interrelated activities and functions that are directed at attracting, developing and maintaining (or disposing of) a firm' s human resources" (Lado \& Wilson, 1994 cited in Atteya, 2012).

Human resources management includes practices of attaining, retaining, empowering and motivating employees (Atteya, 2012). For resort hotels, human resources management is not an easy function because they are characterized by unique staffing, training and development process especially for hourly employees (Hausknecht et al., 2009).

Retention strategies as a part of HRM strategies should have a priority at hotels. As turnover rates increase, retaining employees has become an important issue to the long-term success for any organization and especially for hotels (Choi \& Dickson, 2009; Rathnaweera, 2010). According to Miodonski (2005) and Adi (2012) retention is how to create work environment which endeavor to maintain employees for the long term and avoiding the loss of qualified employees from leaving the organization.

Retention strategies achieve several advantages for hotels. They can enhance employee satisfaction (Cho et al., 2009), reduce job stress (Vasquez, 2014), improve employee commitment and hotel performance and decrease voluntary turnover (Woods et al., 2006). All these factors can contribute to achieve the highest level of service quality (Rader, 2012).

On the contrary, if hotels are unable to retain staff, this will lead to reduce their competitive advantages and capabilities (Kumar et al., 2013; Kay et al., 2009) and increase turnover rates (Goosen et al., 2012).

Kavitha et al., (2011) stated that the main factors to retain employees are communication, training, job satisfaction, pay and benefits. Ismert \& Petrick (2004) claimed that to achieve employees' retention, employees should be satisfied with management, compensation and benefits, co-workers and job tasks.

By using the following practices, resort hotels can improve their employee retention:

\section{Training and development}

Training is an important task performed by the human resources department to provide employees with the necessary knowledge, skills and abilities to work effectively (Hussain \& Sana ur Rahman, 2013; Atteya, 2012).

Liao \& Teng (2010) claimed that training contributes significantly to achieve employee job satisfaction as trained employees are more satisfied than employees who are not trained. When managers are not interested in providing their employees with adequate training and raising their skills, as a result turnover rates increases (Chen et al., 2010).

Training and development have several benefits that affect on the work environment as a whole such as: improving service quality (Eaglen et al., 2000), increasing employee satisfaction (Preenen et al., 2011), creating positive work environment (Kaliprasad, 2006) and reducing employee turnover rates and turnover costs (Chew, 2004). 
Kyndt et al. (2009) found that training and development are positively participated to employee retention as it helps employees to develop their skills and competencies. Mentoring key employees and providing on the job training are considered two ways of training which help in retaining employees to engage (Preenen et al., 2011). Accordingly, the following hypothesis is formulated:

H1: Employee satisfaction and retention are correlated with training and development in resorts.

\section{Rewards and benefits}

Rewards and benefits are key factors that greatly contribute to achieve employees' job satisfaction. They can be divided into direct and indirect financial compensation. Direct financial compensation is salaries while indirect financial compensation represents benefits offered to employees such as healthcare, child care and paid time off (Helalat et al., 2014).

Pay is an important feature of HRM. Woods et al. (2006) and Coetzer et al. (2007) mentioned that there are four types of rewards that could have great impacts on decreasing turnover rates which are pay raises, promotions, bonuses and profit sharing. While pay is an important factor to attract employees, benefits are necessary to retain them (Kozic, 2012). Low pay is a notable feature in hotels which causes a decrease in employees' job satisfaction and lead to higher employee turnover (Kumar et al., 2013; Helalat et al., 2014).

It is beneficial for resort hotel managers to understand that benefits offered to employees should be varied to attract and retain them. These benefits should be comprised meals, accommodation, pension plan and insurance policies (Kozic, 2012). Accordingly, the following hypothesis is formulated:

H2: Employee satisfaction and retention are correlated with rewards \& benefits provided by resorts.

\section{Recognizing}

Lack of recognition is one from the important reasons for leaving the job (Rader, 2012). Recognition has many forms varied from informal such as e-mail appreciation for employees' efforts and gifts to formal such as an annual awards ceremony and the annual employee performance evaluations. Employees' recognition has various advantages as encouraging employees, less turnover, more productivity and more retaining employees (Branham, 2005). Accordingly, the following hypothesis is formulated:

H3: Employee satisfaction and retention are correlated with employees recognition.

\section{Communication}

Communication has defined as the "process through which knowledge and information is shared between team members" (Salas et al., 2008 cited in Hussain \& Sana ur Rahman, 2013). Communication is a significant tool to build employees' commitment in resort hotels (Kozic, 2012). When there is a stronger relationship between managers and employees this will enhance the work environment, decrease employee turnover and increase employee retention rates (Nadiri \& Tanova, 2010). Reducing employee turnover can be achieved by providing open and honest communication between managers and employees (Laver et al., 2008).

Philippe et al. (2009) conducted a study to investigate the effects of managers' communication on employees. They found a significant relationship between communication between managers and employees and employee retention. They also found that open communication enhances the work environment and increases employees' job satisfaction. Accordingly, the following hypothesis is formulated:

H4: Employee satisfaction and retention are correlated with internal communication system in resorts. 


\section{Performance appraisal}

Performance management is mainly focused on the individual performance and development to make sure that the employee performance and outcomes are compatible with the organization goals (Mudor \& Tooksoon, 2011).

Performance appraisal is a significant human resource task (Kuvaas, 2006). By using an effective performance appraisal, organizations can be able to distinguish between high and poor performers and ending poor performers and retain high performers (Bawa \& Jantan, 2005). Performance appraisal has a positive relationship with job satisfaction and organizational commitment and a negative relationship with turnover intentions (Khalid et al., 2011). Poon (2004) confirmed that when employees are dissatisfied with performance appraisal this will affect their job satisfaction and in turn affect their retention. Accordingly, the following hypothesis is formulated:

H5: Employee satisfaction and retention are correlated with performance appraisal in resorts.

\section{Empowerment}

Management style is an important element in employees' retention (Miodonski, 2005). Empowering employees as one of the management styles can be considered a HRM practice. It can be used as an approach to achieve employees job satisfaction (Derani et al., 2009; Kazlauskaite et al., 2012)

According to Seibert et al. (2004) employee empowerment means that leaders give their employees the power of decision making authority and allow them to make a decision. Empowerment can be very useful in the hospitality industry and especially in resort hotels operations; as it can lead to achieve job satisfaction and commitment to the hotel (Clark et al., 2009; Khalid et al., 2011; Arslanturk et al., 2011), increase productivity and service quality (Kazlauskaite et al., 2012), reduce employee turnover and retain them (Derani et al., 2009; Shriberg, 2009).

Gill et al. (2011) examined the relationship of employee empowerment with the intention to quit. They found that there was a negative relationship between employees' empowerment and their intention to quit. Therefore, Hotel managers should empower their employees to decrease their intention to leave and retain them. Accordingly, the following hypothesis is formulated:

H6: Employee satisfaction and retention are correlated with employee empowerment in resorts.

\section{Job Satisfaction}

HRM practices can greatly contribute to achieve employees job satisfaction and reduce their intention to quit. Job satisfaction refers to an employee's positive reaction to his job (Atteya, 2012)

There are several reasons which make employees dissatisfied with their jobs such as low payment, inappropriate resources to succeed, have no role in the decisions that affect the employees, lack of opportunities for promotion (Gumbiner, 2007), job stress and insecurity (Fu et al., 2012). Additionally, the ineffective human resource practices in selection, training and development and performance appraisal can contribute to the employees job dissatisfaction (Atteya, 2012).

Lack of job satisfaction is an effective factor which increase employee turnover (Fu et al., 2012; Ma et al., 2009; Wright \& Bonett, 2007) and turnover costs (Clark et al., 2009).

Messmer (2006) showed four determinants for job satisfaction which are: compensation and benefits, work environment, career development and work/life balance. Nyberg (2010) mentioned that salary, benefits and incentives are the most important elements being contributed to employee retention and job satisfaction. Moreover, formal training as well as empowerment, performance appraisal and flexible work hours are other significant factors to achieve job satisfaction (Brown et al., 2010; Yang, 2010). 
Chen et al. (2010) found a significant relationship between job satisfaction and employee turnover. They also found that employees job satisfaction is a significant factor in employees intention to stay. There are many connections between employees satisfaction and their retention (Kim \& Jogarantnam, 2010). Job satisfaction can play a great role in employees retention (Messmer, 2006). It is found that the job satisfaction is the cornerstone for employee retention (Kozic, 2012). This means if employees are satisfied with their jobs, they will not leave their work and consequently it can be easy to retain them. However, if employees are dissatisfied with their job, their intention to quit will increase (Pepe, 2010).

\section{Methods}

A questionnaire was developed to investigate the HRMPs and employees' satisfaction and retention in five-star resort hotels located in Hurghada and Sharm El-Sheikh. It was designed based on the previous researchers (Chew, 2004; Rathnaweera, 2010; Mensah, 2014) to collect data from the sample. The questionnaire was divided into 3 sections. The first section investigated the perception of employees about some HRMPs in their resorts. Employees were asked to self-rate each item based on the level of practice across their resorts. A 5 point rating scale has been used ranging from 1 (low practice across the resort) to 5 (high practice across the resort). The questions in this section have been under six HRMPs including: training and development (4 items), rewards and benefits (6 items), employee recognition (3 items), internal communication system (4 items), performance appraisal (5 items) and employee empowerment (3 items). The second section was to probe employees' satisfaction and their intention to stay in resort. The last section included the respondents' demographics. The sample included (9) resorts from Hurghada and (13) resorts from Sharm ElSheikh.

\section{Results and Discussion}

Originally, 300 questionnaire forms were distributed. Only 227 forms were returned, and 214 questionnaires were valid giving a valid response rate of $71.3 \%$. Statistical Package for Social Sciences (SPSS) was used for statistical analysis.

The reliability of the scales was tested by using Cronbach' alpha coefficient to measure internal reliability; its value ranging from 0 to 1 , and higher values indicate greater reliability. Cronbach' alpha for this study was higher than 0.97 for the individual constructs and 0.97 for the entire survey as exhibited in table (1). According to Spector (1992) any item greater than 0.7 constitutes an appropriate level of internal consistency reliability. Cronbach' alpha values for all individual constructs were higher than 0.7 .

Table (1) Coefficient of reliability and validity of the survey

\begin{tabular}{|l|l|l|l|}
\hline Constructs & Training \& development & No. of items & Cronbach's Alpha \\
\cline { 2 - 4 } & Rewards and Benefits & 6 & 0.977 \\
\cline { 2 - 4 } & Recognition & 3 & 0.977 \\
\cline { 2 - 4 } variables & Communication & 4 & 0.977 \\
\cline { 2 - 4 } & Performance appraisal & 5 & 0.975 \\
\cline { 2 - 4 } & Empowerment & 3 & 0.977 \\
\cline { 2 - 4 } & Satisfaction & 4 & 0.978 \\
\hline Dependent variable & Retention & 10 & 0.974 \\
\hline \multirow{2}{*}{ Overall survey scale } & $\mathbf{3 9}$ & $\mathbf{0 . 9 7 9}$ \\
\hline
\end{tabular}


Reliability alone is not sufficient to consider that an instrument is adequate. Therefore validity is required to validate the constructs. Before distribution and completion of the questionnaire, its content validity had been examined by two human resource managers with more than five years of experience in the hotel industry and by three academics specializing in human resource management. The questionnaire was adapted according to their comments.

\section{Respondents' Profile}

Table (2) shows the demographic profile of respondents. It was found that 168 respondents $(78.5 \%)$ were male whereas 46 respondents $(21.5 \%)$ were female. The majority of the respondents $(65.4 \%)$ were in the age range from 25 to less than 35 years. This was followed by those aged less than 25 years constituting of $30.8 \%(n=66)$ and those aged 35 to less than 45 years $(2.8 \%)$. On the other hand, only 2 respondents $(0.9 \%)$ fell in the category of age 45 years and more. Single and married respondents were $66.4 \%(n=142)$ and $33.6 \%(n=72)$ respectively

In terms of education qualification, high school was the most obtained educational degree as selected by $(61.7 \%)$, followed by Bachelor of Science $(30.8 \%)$ and post graduate $(7.5 \%)$. In hotel industry, experience is considered more important than educational qualification, thus candidates often started from entry-level positions despite having higher qualifications and were promoted based on their performance (Ahmad \& Zainol, 2011). Therefore, it is not surprising that about two third of investigated employees in resorts had the educational level of high school. They started as nonmanagerial employees and were promoted to higher positions based on their performance (Ghazali et al., 2012).

Concerning the respondents working years in the present resort, most of them $(158 ; 73.8 \%)$ indicated that they work less than one year in the present hotel and 44 employees $(20.6 \%)$ work from 1 to less than 3 years in the present resort. On the other hand, respondents who have 3 to less than 5 working years and who work five years and more were equaled $(6 ; 2.8 \%)$.

Employees who participated in this study were from different departments in the resort. There were 90 respondents $(42 \%)$ worked in F\&B department, 68 respondents $(31.8 \%)$ worked in housekeeping department and 40 respondents $(18.7 \%)$ worked in the front office department. Also, there were 16 respondents $(7.5 \%)$ work in other departments such as engineering, human resource and administration departments.

Table (2) Profile of the Sample

\begin{tabular}{|l|l|l|}
\hline Gender & Frequency & Percent \\
\hline Males & 168 & 78.5 \\
\hline Females & 46 & 21.5 \\
\hline Total & $\mathbf{2 1 4}$ & $\mathbf{1 0 0 . 0}$ \\
\hline Age & Frequency & Percent \\
\hline Less than 25 years & 66 & 30.8 \\
\hline 25 to less than 35 & 140 & 65.4 \\
\hline 35 to less than 45 & 6 & 2.8 \\
\hline 45 years and more & 2 & 0.9 \\
\hline Total & $\mathbf{2 1 4}$ & $\mathbf{1 0 0 . 0}$ \\
\hline
\end{tabular}




\begin{tabular}{|l|l|l|}
\hline Marital Status & Frequency & Percent \\
\hline Single & 142 & 66.4 \\
\hline Married & 72 & 33.6 \\
\hline Total & $\mathbf{2 1 4}$ & $\mathbf{1 0 0 . 0}$ \\
\hline Education & Frequency & Percent \\
\hline High School & 132 & 61.7 \\
\hline Bachelor of science & 66 & 30.8 \\
\hline Post graduate & 16 & 7.5 \\
\hline Total & $\mathbf{2 1 4}$ & $\mathbf{1 0 0 . 0}$ \\
\hline Working tenure & Frequency & Percent \\
\hline Less than one year & 158 & 73.8 \\
\hline One to less than three years & 44 & 20.6 \\
\hline Three to less than five years & 6 & 2.8 \\
\hline five years and more & 6 & 2.8 \\
\hline Total & $\mathbf{2 1 4}$ & $\mathbf{1 0 0 . 0}$ \\
\hline Department & Frequency & Percent \\
\hline Food and beverage & 90 & 42.0 \\
\hline Front office & 40 & 18.7 \\
\hline Housekeeping & 68 & 31.8 \\
\hline Other & 16 & 7.5 \\
\hline Total & $\mathbf{2 1 4}$ & $\mathbf{1 0 0 . 0}$ \\
\hline
\end{tabular}

\section{HRMPs and Employees' Satisfaction, and Retention}

It is observed from the following table (3) that employee retention shares a high statistically significant and positive relationship with employee satisfaction $(\mathrm{r}=0.708, \mathrm{p}<0.01)$, training and development $(\mathrm{r}=0.667, \mathrm{p}<0.01)$, rewards and benefits $(\mathrm{r}=0.690, \mathrm{p}<0.01)$, recognition $(\mathrm{r}=0.747$, $\mathrm{p}<0.01)$, communication $(\mathrm{r}=0.730, \mathrm{p}<0.01)$, performance appraisal $(\mathrm{r}=0.790, \mathrm{p}<0.01)$ and employee empowerment $(\mathrm{r}=0.874, \mathrm{p}<0.01)$.

Table (3) Correlation matrix of the study variables

\begin{tabular}{|c|c|c|c|c|c|c|c|c|}
\hline & 1 & 2 & 3 & 4 & 5 & 6 & 7 & 8 \\
\hline Retention & 1 & & & & & & & \\
\hline Satisfaction & $\begin{array}{l}.708^{* *} \\
.000 \\
214\end{array}$ & 1 & & & & & & \\
\hline $\begin{array}{l}\text { Training \& } \\
\text { Development }\end{array}$ & $\begin{array}{l}.667 * * \\
.000 \\
214\end{array}$ & $\begin{array}{l}.691 * * \\
.000 \\
214\end{array}$ & 1 & & & & & \\
\hline $\begin{array}{l}\text { Rewards \& } \\
\text { Benefits }\end{array}$ & $\begin{array}{l}.690 * * \\
.000 \\
214\end{array}$ & $\begin{array}{l}.847^{* * *} \\
.000 \\
214\end{array}$ & $\begin{array}{l}.535^{* *} \\
.000 \\
214\end{array}$ & 1 & & & & \\
\hline Recognition & $.747^{* * *}$ & $.880^{* * *}$ & $.746^{* * *}$ & $.825^{* * *}$ & 1 & & & \\
\hline
\end{tabular}




\begin{tabular}{|l|l|l|l|l|l|l|l|l|}
\hline & .000 & .000 & .000 & .000 & & & & \\
& 214 & 214 & 214 & 214 & & & & \\
\hline \multirow{3}{*}{ Communication } & $.730^{* *}$ & $.833^{* *}$ & $.815^{* *}$ & $.772^{* *}$ & $.894^{* *}$ & 1 & & \\
& .000 & .000 & .000 & .000 & .000 & & & \\
& 214 & 214 & 214 & 214 & 214 & & & \\
\hline Performance & $.790^{* *}$ & $.869^{* *}$ & $.640^{* *}$ & $.826^{* *}$ & $.770^{* *}$ & $.793^{* *}$ & 1 & \\
appraisal & .000 & .000 & .000 & .000 & .000 & .000 & & \\
\hline \multirow{2}{*}{ empowerment } & 214 & 214 & 214 & 214 & 214 & 214 & & \\
\hline
\end{tabular}

\section{Training and development}

As shown from table (4) that there is a high statistically significant and positive relationship between training \& development items and employees job satisfaction, and retention. Correlation coefficient of all items is significant at the 0.01 level

Table (4) Relationship between training \& development items and employee's retention

\begin{tabular}{|c|c|c|c|}
\hline Training \& development & \multicolumn{2}{|c|}{ Satisfaction } & Retention \\
\hline \multirow{2}{*}{ I get training to do my job well. } & Pearson & $0.511 * *$ & $0.483 * *$ \\
\hline & Sig. & .000 & .000 \\
\hline \multirow[t]{2}{*}{ Available provided training match with my job. } & Pearson & $0.722 * *$ & $0.704 * *$ \\
\hline & Sig. & .000 & .000 \\
\hline \multirow{2}{*}{$\begin{array}{l}\text { The hotel provides regular opportunities for personnel } \\
\text { and career development }\end{array}$} & Sig. & $0.634 * *$ & $0.739 * *$ \\
\hline & Pearson & .000 & .000 \\
\hline \multirow{2}{*}{ Innovation and creativity are encouraged in this hotel } & Sig. & $0.698^{* * *}$ & $0.601 * *$ \\
\hline & Pearson & .000 & .000 \\
\hline
\end{tabular}

The previous tabulated results indicate that employees satisfaction can be enhanced by giving chances to employees for learning and effective training (Liao \& Teng, 2010; Preenen et al., 2011). Likewise, employees' retention rate can be increased if resorts are keen to provide their employees with chances of training and development as they help employees to develop their skills and competencies (Kyndt et al., 2009; Arnold, 2005; Herman, 2005; Hussain \& Sana ur Rahman, 2013). This result supported (H1).

To investigate the role of training and development practice on employees retaining, regression analysis was conducted. The value of adjusted $\mathrm{R}^{2}$ is $(0.637), \mathrm{F}$ value equal 374.583 and significant at 0.000 , pointing that $63.7 \%$ of total variance in employee retention is explained by training \& training practice as shown in table (5). This means that resorts should provide regular opportunities for training \& development due to their important role in retaining employees. Chew \& Chan (2008) stated that employee retention would increase if training could result in higher productivity which indirectly could increase the salary of employees. 
Table (5) The Impact of training \& development on employee retention

\begin{tabular}{|c|c|c|c|c|c|c|c|c|}
\hline $\mathbf{R}$ & \multicolumn{2}{|c|}{ R-Square } & \multicolumn{3}{|c|}{ Adjusted R Square } & \multicolumn{3}{|c|}{ Std. Error of the Estimate } \\
\hline .799 (a) & \multicolumn{2}{|c|}{.639} & \multicolumn{3}{|c|}{.637} & \multicolumn{3}{|c|}{2.639} \\
\hline \multicolumn{9}{|c|}{ ANOVA(b) } \\
\hline & & \multicolumn{2}{|c|}{$\begin{array}{l}\text { Sum of } \\
\text { Squares }\end{array}$} & df & \multicolumn{2}{|c|}{$\begin{array}{c}\text { Mean } \\
\text { Square }\end{array}$} & $\mathbf{F}$ & Sig. \\
\hline Regression & & \multicolumn{2}{|c|}{2609.962} & 1 & \multicolumn{2}{|c|}{2609.962} & 374.583 & $0.000(\mathrm{a})$ \\
\hline Residual & & \multicolumn{2}{|c|}{1477.141} & $\begin{array}{c}21 \\
2\end{array}$ & \multicolumn{2}{|c|}{6.968} & & \\
\hline Total & & \multicolumn{2}{|c|}{4087.103} & $\begin{array}{c}21 \\
3\end{array}$ & & & & \\
\hline \multicolumn{9}{|c|}{ Coefficients(a) } \\
\hline & & \multicolumn{3}{|c|}{$\begin{array}{l}\text { Unstandardized } \\
\text { Coefficients }\end{array}$} & \multicolumn{2}{|c|}{$\begin{array}{c}\text { Standardize } \\
\text { d } \\
\text { Coefficients }\end{array}$} & \multirow[t]{2}{*}{$\mathbf{t}$} & Sig. \\
\hline & & B & \multicolumn{2}{|c|}{ Std. Error } & \multicolumn{2}{|c|}{ Beta } & & \\
\hline (Constant) & & 19.048 & \multicolumn{2}{|c|}{.561} & & & 33.960 & .000 \\
\hline $\begin{array}{l}\text { Training } \\
\text { developmen }\end{array}$ & $\boldsymbol{\&}$ & .937 & \multicolumn{2}{|c|}{.048} & \multicolumn{2}{|c|}{.799} & 19.354 & .000 \\
\hline
\end{tabular}

\section{Rewards and benefits}

Pearson correlation coefficient indicates that all items of rewards and benefits construct are positive correlated and high significant with employees job satisfaction, and retention which supported (H2) as seen in table (6).

Table (6) Relationship between rewards \& benefits and employee's satisfaction, and retention

\begin{tabular}{|c|c|c|c|}
\hline Rewards \& Benefits & \multicolumn{2}{|c|}{ Satisfaction } & Retention \\
\hline \multirow{2}{*}{$\begin{array}{l}\text { Available benefits are appropriate for my } \\
\text { needs }\end{array}$} & Pearson & $0.757 * *$ & $0.713^{* *}$ \\
\hline & Sig. & .000 & .000 \\
\hline \multirow{2}{*}{$\begin{array}{l}\text { Rewards \& benefits are provided based on } \\
\text { the performance }\end{array}$} & Pearson & $0.810^{* *}$ & $0.709^{* *}$ \\
\hline & Sig. & .000 & .000 \\
\hline \multirow{2}{*}{ I know the criteria used to decide my pay } & Pearson & $0.855^{* * *}$ & $0.679 * *$ \\
\hline & Sig. & .000 & .000 \\
\hline \multirow{2}{*}{$\begin{array}{l}\text { My salary is fair for my tasks, duties, and } \\
\text { responsibilities of my job. }\end{array}$} & Pearson & $0.488 * *$ & $0.463^{* *}$ \\
\hline & Sig. & .000 & .000 \\
\hline \multirow{2}{*}{$\begin{array}{l}\text { I earn more than others who occupy similar } \\
\text { positions in other hotels }\end{array}$} & Pearson & $0.422 * *$ & $0.247 * *$ \\
\hline & Sig. & .000 & .000 \\
\hline \multirow{2}{*}{$\begin{array}{l}\text { Rewards \& benefits are satisfactory reviewed } \\
\text { from time to time. }\end{array}$} & Pearson & $0.531^{* *}$ & $0.556^{* *}$ \\
\hline & Sig. & .000 & .000 \\
\hline
\end{tabular}


It can be concluded from regression analysis that the value of adjusted $\mathrm{R}^{2}$ is 0.60 and $\mathrm{f}=320.491(\mathrm{p}<$ 0.01) that indicate rewards and benefits provided by resorts account for $60 \%$ of the variance in employee retention (see table 7). In other words, rewards and benefits have a great contribution in retaining employees in the investigated resorts. Mudor and Tooksoon (2011) and Kozic (2012) assured that pay rates and benefits are able to retain high quality employees especially when they are greater than other competitors and thereby reducing their intention to leave.

Table (7) The Impact of rewards \& benefits on employee retention

\begin{tabular}{|c|c|c|c|c|c|c|c|}
\hline $\mathbf{R}$ & \multicolumn{2}{|c|}{ R-Square } & \multicolumn{2}{|c|}{ Adjusted R Square } & \multicolumn{3}{|c|}{ Std. Error of the Estimate } \\
\hline $.776(a)$ & \multicolumn{2}{|c|}{.602} & \multicolumn{2}{|l|}{.600} & \multicolumn{3}{|c|}{2.770} \\
\hline \multicolumn{8}{|c|}{ ANOVA(b) } \\
\hline & \multicolumn{2}{|c|}{$\begin{array}{c}\text { Sum of } \\
\text { Squares }\end{array}$} & df & \multicolumn{2}{|c|}{$\begin{array}{c}\text { Mean } \\
\text { Square }\end{array}$} & $\mathbf{F}$ & Sig. \\
\hline Regression & \multicolumn{2}{|c|}{2459.690} & 1 & \multicolumn{2}{|c|}{2459.690} & 320.419 & $0.000(a)$ \\
\hline Residual & \multicolumn{2}{|c|}{1627.412} & 212 & \multirow{2}{*}{\multicolumn{2}{|c|}{7.676}} & & \\
\hline Total & 408 & 103 & 213 & & & & \\
\hline \multicolumn{8}{|c|}{ Coefficients(a) } \\
\hline & & \multicolumn{2}{|c|}{$\begin{array}{l}\text { Unstandardizd } \\
\text { Coefficients }\end{array}$} & \multicolumn{2}{|c|}{$\begin{array}{c}\text { Standardize } \\
\text { d } \\
\text { Coefficients }\end{array}$} & $\mathbf{t}$ & Sig. \\
\hline & & B & $\begin{array}{c}\text { Std. } \\
\text { Error }\end{array}$ & & Beta & & \\
\hline (Constant) & & 19.693 & .571 & & & 34.515 & .000 \\
\hline $\begin{array}{l}\text { Rewards } \\
\text { Benefits }\end{array}$ & \& & .680 & .038 & & .776 & 17.900 & .000 \\
\hline
\end{tabular}

\section{Recognition}

Table $(8)$ indicates high significant $(\mathrm{p}<0.01)$ relationship between all items of employee recognition and employee satisfaction, and retention. The level of the relationship (high-moderate to strong) between variables indicates that appreciation of employees is crucial to satisfy and retain them. From this result, (H3) can be accepted.

Table (8) Relationship between employee recognition and employee's satisfaction and retention

\begin{tabular}{|c|c|c|c|}
\hline Recognition & \multicolumn{2}{|c|}{ Satisfaction } & \multirow{2}{*}{$\begin{array}{c}\text { Retentio } \\
\mathbf{n} \\
0.763^{* *} \\
\end{array}$} \\
\hline \multirow{2}{*}{$\begin{array}{l}\text { I have positive recognition when I produce high } \\
\text { quality work. }\end{array}$} & Pearson & $0.816^{* *}$ & \\
\hline & Sig. & .000 & .000 \\
\hline \multirow{2}{*}{ The hotel offers good opportunities for promotion. } & Pearson & $0.776^{* *}$ & $0.639 * *$ \\
\hline & Sig. & .000 & .000 \\
\hline \multirow{2}{*}{$\begin{array}{l}\text { The hotel gives enough recognition for well done } \\
\text { work }\end{array}$} & Pearson & $0.665^{* *}$ & $0.603 * *$ \\
\hline & Sig. & .000 & .000 \\
\hline
\end{tabular}


adjusted $R^{2}$ is 0.612 and $F$ value is $337.594(\mathrm{p}=0.000)$ that reveals employee recognition has significantly explained the $61.2 \%$ of the variance in employee retention. Regression coefficient (B) is $1.122(0.000)$ which is significantly $(\mathrm{t}=18.374 ; \mathrm{p}=0.000)$ at the $1 \%$ significance level as shown in table (9). These results show that employee recognition has a great importance in retaining employee in this study. These results agree with what reported by Chew (2004) and Branham (2005) that employees tend to be stayed when they feel their capabilities, efforts and performance contributions are recognized and appreciated by management.

Table (9) The impact of employee recognition on employee retention

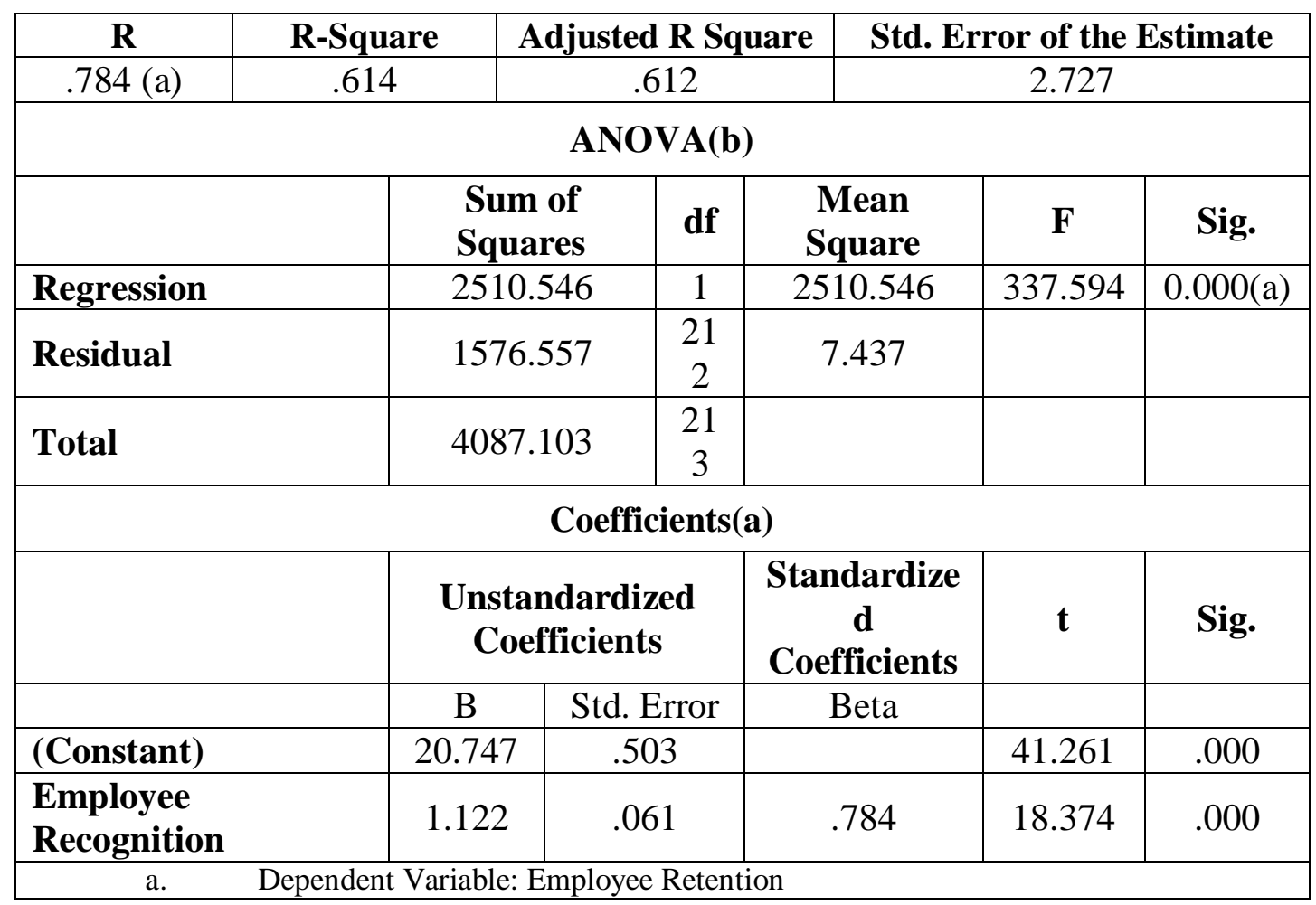

\section{Internal communication system}

A positive, strong and high significant relationship is found between employee satisfaction, and retention and all items of internal communication system structure (see table 10). In other words, when resorts enhance their internal communication systems then the level of employee satisfaction and retention will increase which means that $(\mathrm{H} 4)$ is accepted.

Table (10) Relationship between internal communication system and employee's satisfaction and retention

\begin{tabular}{|c|c|c|c|}
\hline Internal Communication System & \multicolumn{2}{|c|}{ Satisfaction } & Retentio \\
\hline \multirow{2}{*}{$\begin{array}{l}\text { The hotel keeps employees well-informed on matters } \\
\text { important to them. }\end{array}$} & Pearson & $0.605^{* *}$ & $0.629 * *$ \\
\hline & Sig. & .000 & .000 \\
\hline \multirow{2}{*}{ Communication across all levels tends to be good. } & Pearson & $0.814 * *$ & $0.712^{* *}$ \\
\hline & Sig. & .000 & .000 \\
\hline
\end{tabular}




\begin{tabular}{|l|c|c|c|}
\hline Hotel structure encourages horizontal and vertical & Pearson & $0.701^{* *}$ & $0.695^{* *}$ \\
\cline { 2 - 4 } communication. & Sig. & .000 & .000 \\
\hline $\begin{array}{l}\text { There is trust between employees and their } \\
\text { supervisors/team leaders. }\end{array}$ & Pearson & $0.769^{* *}$ & $0.669^{* *}$ \\
\cline { 2 - 4 } & Sig. & .000 & .000 \\
\hline Note: $* *$ Correlation is significant at the 0.01 level (2-tailed). \\
\hline
\end{tabular}

From the results of simple linear regression presented in table (11), the adjusted $\mathrm{R}^{2}$ is $(0.643), \mathrm{F}$ value is $383.874(\mathrm{p}=0.000)$ and significant at the $1 \%$ of significance level, indicating that $64.3 \%$ of total variance in employee retention is explained by internal communication system. This result assures the importance of internal communication system in raising resort employee retention. It can be concluded that when open communication system is implemented in a resort and employees are allowed to openly communicated with their coworkers, share their ideas, knowledge and information with other colleagues then it would increase the level of employees job satisfaction and retention (Philippe et al., 2009). In the same context, Chang \& Chang (2008) assure that the availability of good internal communication system provides a path for employees to express their opinions, cultures and other traditions which could reduce the employee's intention to leave.

Table (11) The impact of internal communication system on employee retention

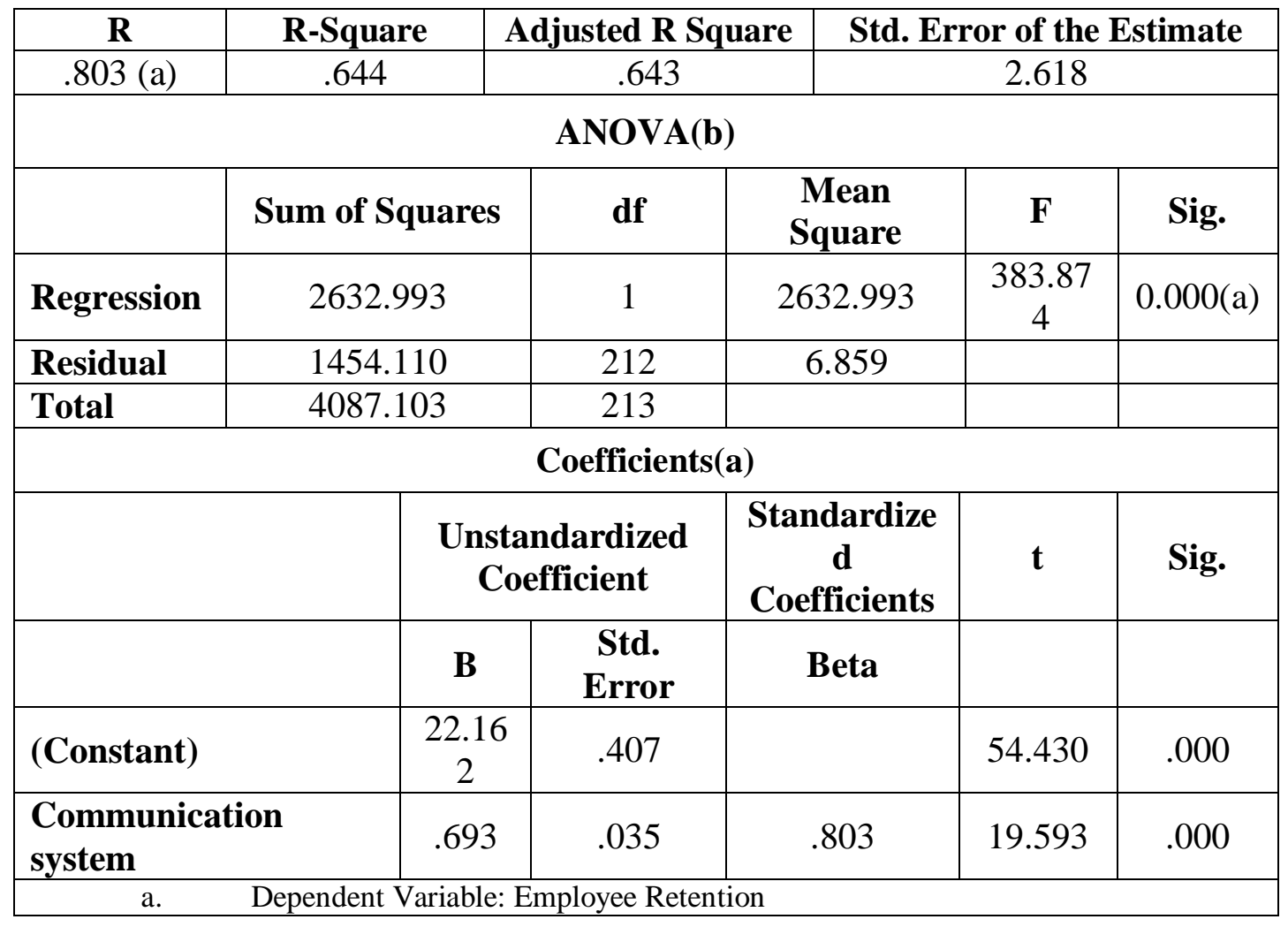

\section{Performance appraisal}

According to table (12), there is positive and high significant association between the five items of the performance appraisal and employee satisfaction and retention. This means that when employees' 
efforts are acknowledged and appraised by their management, this can enhance their job satisfaction and in turn increase employees' retention level. Hence, (H5) is supported.

Table (12) Relationship between performance appraisal items and employee's satisfaction and retention

\begin{tabular}{|c|c|c|c|}
\hline Performance Appraisal & \multicolumn{2}{|c|}{ Satisfaction } & $\underset{n}{\text { Retentio }}$ \\
\hline \multirow{2}{*}{ Performance appraisal system is fair. } & Pearson & $0.482 * *$ & $0.553^{* *}$ \\
\hline & Sig. & .000 & .000 \\
\hline \multirow{2}{*}{$\begin{array}{l}\text { There is a formal and written performance appraisal } \\
\text { system. }\end{array}$} & Pearson & $0.753 * *$ & $0.740 * *$ \\
\hline & Sig. & .000 & .000 \\
\hline \multirow{2}{*}{ I'm informed that how my performance is evaluated. } & Pearson & $0.725 * *$ & $0.576^{* *}$ \\
\hline & Sig. & .000 & .000 \\
\hline \multirow{2}{*}{$\begin{array}{l}\text { I receive feedback of performance evaluation results } \\
\text { about myself. }\end{array}$} & Pearson & $0.818^{* * *}$ & $0.688^{* *}$ \\
\hline & Sig. & .000 & .000 \\
\hline \multirow{2}{*}{ Performance appraisal is done by the supervisor. } & Pearson & $0.844 * *$ & $0.833^{* *}$ \\
\hline & Sig. & .000 & .000 \\
\hline
\end{tabular}

Regression analysis explores that adjusted $\mathrm{R}^{2}$ is 0.595 and $\mathrm{F}=314.540$ (significant at $\mathrm{p}=0.000$ ) that indicates $59.5 \%$ of total variance in employee retention is explained by the five items of performance appraisal jointly as shown in table (13). Performance appraisal can contribute greatly to employees' satisfaction and retention as it has a positive relationship with job satisfaction and a negative relationship with turnover intentions (Poon, 2004; Khalid et al., 2011)

Table (13) The Impact of performance appraisal on employee retention

\begin{tabular}{|l|l|l|l|l|l|l|}
\hline R & R-Square & Adjusted R Square & Std. Error of the Estimate \\
\hline .773 (a) & .597 & .595 & 2.786 \\
\hline ANOVA(b) & $\begin{array}{l}\text { Sum of } \\
\text { Squares }\end{array}$ & df & Mean Square & F & Sig. \\
\hline & 2441.519 & 1 & 2441.519 & 314.540 & $0.000(a)$ \\
\hline Regression & 1645.584 & 212 & 7.762 & & \\
\hline Residual & 4087.103 & 213 & & & \\
\hline Total & $\begin{array}{l}\text { Unstandardized } \\
\text { Coefficients }\end{array}$ & Std. Error & Beta \\
\hline \\
\hline
\end{tabular}




\section{Empowerment}

Regarding the sixth hypothesis, the result in table (14) illustrates that there is a positive relationship at the significance level of $1 \%$ between empowerment and employee satisfaction $(r=78.9-81.4)$, and retention $(\mathrm{r}=67.7-73.7)$ which means that this hypothesis is accepted. This result indicates that when resort management is empowering their employees by enable them to contribute in decision-making process and solve their work problems, this would enhance the intention of employee to stay.

Table (14) Relationship between items of empowerment and employee's satisfaction, and retention

\begin{tabular}{|c|c|c|c|}
\hline Empowerment & \multicolumn{2}{|c|}{ Satisfaction } & Retentio \\
\hline \multirow{2}{*}{$\begin{array}{l}\text { I am allowed to solve problems by using my } \\
\text { judgment. }\end{array}$} & Pearson & $0.814 * *$ & $0.737 * *$ \\
\hline & Sig. & .000 & .000 \\
\hline \multirow{2}{*}{ I am allowed to decide how I do my job } & Pearson & $0.796^{* *}$ & 0.729 ** \\
\hline & Sig. & .000 & .000 \\
\hline \multirow{2}{*}{ I have freedom I need to do my job well. } & Pearson & $0.789 * *$ & $0.676^{* *}$ \\
\hline & Sig. & .000 & .000 \\
\hline
\end{tabular}

observed from the following table (15) that the adjusted $\mathrm{R}^{2}$ is 0.476 and $\mathrm{F}$ value equal 194.670 $(p<0.01)$. These figures reveal that $47.6 \%$ of total variance in employee retention is explained by empowerment. Chang and Chang (2008) and Gill et al. (2011) evidenced a negative significant relationship between employees' empowerment and their intention to leave. Employees should be empowered, especially the front line employees in the resort to cope with the unexpected service and the customer requirements, while the manager plays the role of authorization and also provides training for the employees.

Table (15) The Impact of empowerment on employee retention

\begin{tabular}{|c|c|c|c|c|c|c|}
\hline $\mathbf{R}$ & R-Square & \multicolumn{2}{|c|}{ Adjusted R Square } & \multicolumn{3}{|c|}{ Std. Error of the Estimate } \\
\hline $.692(a)$ & .479 & \multicolumn{2}{|c|}{.476} & \multicolumn{3}{|c|}{3.170} \\
\hline \multicolumn{7}{|c|}{$\operatorname{ANOVA}(\mathbf{b})$} \\
\hline & $\begin{array}{c}\text { Sum of } \\
\text { Squares }\end{array}$ & df & \multicolumn{2}{|c|}{ Mean Square } & $\mathbf{F}$ & Sig. \\
\hline Regression & 1956.469 & 1 & \multicolumn{2}{|c|}{1956.469} & 194.670 & $0.000(a)$ \\
\hline Residual & 2130.634 & 212 & \multicolumn{2}{|c|}{10.050} & & \\
\hline Total & 4087.103 & 213 & & & & \\
\hline \multicolumn{7}{|c|}{ Coefficients(a) } \\
\hline & \multicolumn{2}{|c|}{$\begin{array}{c}\text { Unstandardized } \\
\text { Coefficients }\end{array}$} & \multicolumn{2}{|c|}{$\begin{array}{c}\text { Standardized } \\
\text { Coefficients }\end{array}$} & \multirow[t]{2}{*}{$\mathbf{t}$} & \multirow[t]{2}{*}{ Sig. } \\
\hline & $\mathbf{B}$ & Std. Error & \multicolumn{2}{|c|}{ Beta } & & \\
\hline (Constant) & 22.944 & .506 & & & 45.325 & .000 \\
\hline $\begin{array}{l}\text { empowermen } \\
\mathbf{t}\end{array}$ & .990 & .071 & \multicolumn{2}{|c|}{.692} & 13.952 & .000 \\
\hline a. & \multicolumn{6}{|c|}{ ependent Variable: Employee Retention } \\
\hline
\end{tabular}




\section{Proposed Model for Estimating Employee Retention}

The proposed model of employee retention through implementing HRMPs is obtained from the following tabulated results as shown in table (16):

Table (16): parameter of employee retention estimation

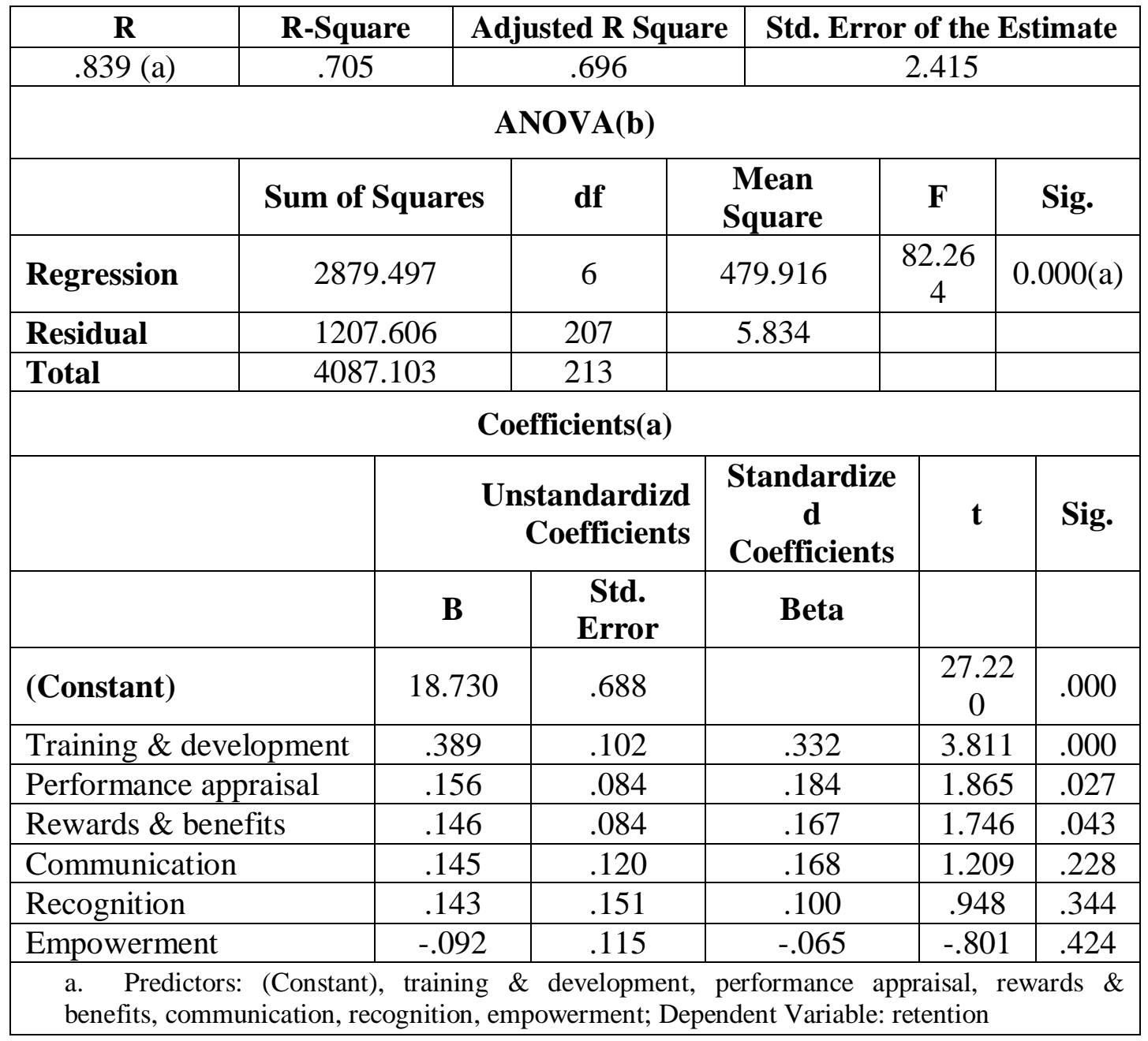

Employee retention $=\beta 0+\beta 1$ training $\&$ development $+\beta 2$ Performance appraisal $+\beta 3$ rewards $\&$ benefits.

There is a significant relationship between employee retention and three HRM practices; training and development, performance appraisal and rewards \& benefits. These three practices impact with significant and positive coefficient on employee retention. This result means that if the implementation level of one of these three practices increases then the level of employee retention will also increase. Other three HRMPs including, internal communication system, employee recognition and employee empowerment are excluded from the proposed model because they have low and negative coefficients. It is concluded from the proposed model that the increase in the implementation level of training \& development would increase the level of employee retention by (0.389) which is the highest coefficient among other coefficients. On the other hand, empowerment has the lowest and negative effect (- 0.092) on employees' retention in five-star resorts. 


\section{Conclusion}

Employees are considered a significant reason for any hotel operation success. Employees' satisfaction and retention are among the main challenges for human resources management. The objective of this study was to investigate the relationship between some of the HRM practices and employees' satisfaction and retention at resorts and how these practices contribute to retain them.

Although, there are numerous HRM practices used by hotel operations to retain their employees, the study has concentrated on six practices namely: training and development, rewards and benefits, recognizing, internal communication system, performance appraisal and employees empowerment. All these practices have significant correlations with employees' satisfaction, and retention. However, training and development, performance appraisal and rewards and benefits have greater and significant impact than the other three HRM practices.

On the whole, the study provides resort managers a vision to design their own strategies to keep their employees.

\section{References}

- Adi, N. A. (2012) 'Driving performance and Retention to employee engagement: A case study in university of Brawijaya', Journal of Basic and Applied Scientific Research, 2 (1), 338-350.

- Ahmad, R. \& Zainol, N. Z. (2011) 'what it takes to be a manager: The case of Malaysian five star resort hotels', 2nd International Conference on Business and Economic Research (2nd Icber 2011) Proceeding, 2040-2051.

- Arnold, E. (2005) 'Managing human resources to improve employee retention', Health Care Manager, 24(2), 132-140.

- Arslanturk,Y.; Ozturk, Y. \& Pelit, E. (2011) 'The effects of employee empowerment on employee job satisfaction: A study on hotels in Turkey', International Journal of Contemporary Hospitality Management, 23 (6), 784-802.

- Atteya, M.N. (2012) 'Testing the impact of the human resource management practices on job performance: An empirical study in the Egyptian joint venture petroleum companies', International Journal of Business and Social Science, 3 (9), 105-119.

- Bawa, A.M. \& Jantan, M. (2005) 'Human resource practices as determinants of employee turnover: An empirical investigation', Asian Academy of Management Journal, 10 (2), 69-80.

- Birdir, K. (2002) 'General manager turnover and root causes' International Journal of Contemporary Hospitality Management, 14 (1), 43-47.

- Blomme, R. J., Van Rheede, A., \& Tromp, D. M. (2010) 'The use of the psychological contract to explain turnover intention in the hospitality industry: A research study on the impact of gender on the turnover intentions of highly educated employees' International Journal of Human Resources Management, 21(1), 144-162.

- Branham, L. (2005) 'The Seven Hidden Reasons Employees Leave-How to Recognize the Subtle Signs and Act Before It Is Too Late, U.S.A: AMacom.

- Brown, M.; Hyatt, D., \& Benson, J. (2010) 'Consequences of the performance appraisal experience' Personnel Review, 39, 375-396.

- Chang, C. P. \& Chang, W. C. (2008) 'Internal marketing practices and employees' turnover intentions in tourism and leisure hotels', The Journal of Human Resource and Adult Learning, 4(2), 161-172.

- Chen, Y; Wang, W.C \& Chu, Y.C. (2010) 'Structural investigation of the relationship between working satisfaction and employee turnover' Journal of Human Resource and Adult Learning, 6, 41-50.

- Chew, J.L. (2004) 'The influence of human resource management practices on the retention of core employees of Australian organizations: An empirical study', Ph.D Thesis, Murdock University, Australia.

- Chew, J. \& Chan, C. C. A. (2008) 'Human resource practices, organizational commitment and intention to stay', International Journal of Manpower, 29(6), 503-522.

- Cho, S.; Johanson, M.M. \& Guchait, P. (2009) 'Employees intent to leave: A comparison of determinants of intent to leave versus intent to stay', International Journal of Hospitality Management, 28, 374-381. 
- Choi, Y., \& Dickson, R.D (2009) 'A case study into the benefits of management training programs: Impacts on hotel employee turnover and satisfaction level' Journal of Human Resources in Hospitality \& Tourism, 9 (1), 103-116.

- Clark, A.R.; Hartline, D.M \& Jones, C.K. (2009) 'The effects of leadership style on hotels employees' commitment to service quality’ Cornell Hospitality Quarterly, 50 (2), 209-231.

- Coetzer, A.; Cameron, A.; Lewis, K.; Massey, C. \& Harris, C. (2007) 'Human resource management practices in selected New Zealand small and medium-sized enterprises', International Journal of Organizational Behavior, 12 (1), 17-32.

- Costen, W. \& Salazar, J. (2011) 'The impact of training and development on employee job satisfaction, loyalty and intent to stay in the lodging industry' Journal of Human Resources in Hospitality\& tourism, 10 (3), $273-284$.

- Derani, N.; Zain, A.R.; Adzmy, A.; Abdullah, R.; Radzi, M.S \& Abd Patah, R. M (2009) 'The influence of psychological empowerment on overall job satisfaction of front office receptionists, International Journal of Business and Management, 4 (11), 167-176.

- Eaglen, A., Lashley, C. \& Thomas, R. (2000) 'Modelling the benefits of training to business performance in leisure retailing' Strategic Change, 9 (1), 311-325.

- Enz, A. C. (2001) 'What keeps you up at night? Key issues of concern for lodging managers', Cornell Hotel and Restaurant Administration Quarterly, 42 (2), 38-45.

- Fan, K.C.; Lee, T. Z. \& Su, H.W. (2011) Turnover Determinants of new employees in international hotels', Journal of Service Science and Management, 4, 158-164.

- $\quad$ Fu, J. Y.; Wan, S.C. \& Yang, T. J. (2012) 'Qualitative examination of employee turnover and retention strategies in international tourist hotels in Taiwan, International Journal of Hospitality Management, 31, 837-848.

- Ghazali, H.; Nasyuki, N.M.; Yi, O. X. \& Ishak, M. B. (2012) 'Human Resource Practice and Employees' Intention to Stay in the Kuala Lumpur Hotel Industry', Journal of Tourism, Hospitality \& Culinary Arts, 4 (1), 88-118.

- Gill, A.; Mathur, N.; Sharma, S. \& Bhutani, S. (2011) 'The effects of empowerment and transformational leadership on employee intentions to quit: A study of restaurant workers in India' International Journal of Management, 28, 217-229.

- Goosen, X.; Goldman, G. A. \& Mohlala, J. (2012) 'Employee retention within the information technology division of south African bank', South African Journal of Human Resource Management, 10 (2), 1-11.

- Gumbiner, D. M. (2007) 'Manager retention and the steamboat ski resort', Master Thesis, Graduate college, University of Nevada, Las Vegas.

- Hausknecht, P.J.; Rodda, J. \& Howard, J.M. (2009) 'Targeted employee retention: Performance-based and jobrelated differences in reported reasons for staying', Human Resource Management, 48 (2), 269-288.

- Helalat, S.A; Albattat, R.A. \& Matsom, P.A. (2014) 'Higher dissatisfaction higher turnover in the hospitality industry', International Journal of Academic Research in Business and Social Sciences, 4 (2), 45-52.

- Herman, R.E., (2005) 'HR managers as employee-retention specialists', Employment Relations Today, 32(2), 1-7.

- Hussain and Sana ur Rehman (2013) 'Do Human Resource Management Practices Inspire Employees' Retention?', Research Journal of Applied Sciences, Engineering and Technology, 6(19), 3625-3633.

- Ismert, M. \& Petrick, F. (2004) 'Indicators and standards of quality related to seasonal employment in the ski industry', Journal of Travel Research, 43, 46-56.

- James, L. \& Mathew, L. (2012) 'Employee retention strategies: IT industry', Journal of Indian Management, 9 (3), 79-87.

- Kaliprasad, M. (2006) 'The human Factor: Attracting, retaining and motivating capable people', Cost Engineering, 48 (6), 20-26.

- Kavitha, S.R.; Geetha, S.R. \& Arunachalam, V. (2011) 'An empirical study on employee retention strategies in a biscuit manufacturing company in India', Interdisciplinary Journal of Contemporary Research in Business', 3, 762-772.

- Kay, C.; Moncarz, E. \& Zhao, J. (2009) 'An exploratory study of U.S lodging properties' organizational practices on employee turnover and retention', International Journal of Contemporary Hospitality Management, 21(4), 437-458.

- Kazlauskaite, R.; Buciuniene, I. \& Turauskas, (2012) 'Organizational and psychological empowerment in the HRM-performance linkage’, Employee Relations, 34 (2), 1- 15. 
- Khalid, K.; Rahman, R.; Zahari, H.; Musa, M. \& Abdullah, R. (2011) 'The study of employee satisfaction and its effects towards loyalty in hotel industry in Klang valley, Malaysia' International Journal of Business and Social Science, 2 (3), 147-155.

- Kim, K. \& Jogarantnam, G. (2010) 'Effects of individual and organizational factors on job satisfaction and intent to stay in the hotel and restaurant industry', Journal of Human Resources in Hospitality and Tourism, 9, 318-339.

- Kozic, P.S. (2012) 'Managers' perceptions on how management practices affect employee retention in resort hotels', Doctoral Thesis, Wilmington University.

- Kumar, B.; Lengler, J. \& Mohsin, A. (2013) 'Exploring the antecedents of intentions to leave the job: The case of luxury hotel staff', International Journal of Hospitality Management, 35, 48-58.

- Kuria, S.; Alice, O. \& Wanderi, M.P. (2012) 'Assessment of labour turnover in three and five star-rated hotels in Kenya’, International Journal of Business and Social Science, 3 (15), 311-317.

- Kuvaas, B. (2006) 'Performance appraisal satisfaction and employee outcomes: Mediating and moderating roles of work motivation', The International Journal of Human Resource Management, 17 (3), 504-522.

- Kyndt, E.; Dochy, F.; Michielsen, M. \& Moeyaert, B. (2009) 'Employee retention: organizational and personal perspectives', Springer Science, 1-21.

- Lado, A. A. \& Wilson, M. (1994) 'Human resource systems and sustained competitive advantage: A competitive advantage: A competence based perspective', Academy of Management Review, 19, 699-727 cited in Atteya, M. N. (2012) 'Testing the impact of the human resource management practices on job performance: An empirical study in the Egyptian joint venture petroleum companies', International Journal of Business and Social Science, 3 (9), 105-119.

- Lashely, C. (2001) 'Costing staff turnover in hospitality service organizations', Journal of Services Research, 1 (2), 3-24.

- Laver, B.; Jayawardena, C. \& Willie, P. (2008) 'Attracting and retaining quality human resources for Niagra' s hospitality industry', International Journal of Contemporary Hospitality Management, 20 (3), 293-301.

- Liao, W. \& Teng, M. (2010) 'The relationship between ethics training and employee satisfaction: A mediator of corporate responsibility practices', Journal of Human Resource and Adult learning, 6, 9-18

- Ma, J.C.; Lee, P.H.; Yang, Y.C. \& Chang, W.Y. (2009) 'Predicting factors related to nurses' intention to leave, job satisfaction and perception of quality of care in acute care hospitals', Nursing Economics, 27 (3), $178-184$.

- Mensah, R. (2014) "Effects of human resource management practices on retention of employees in the banking industry in Accra, Ghana", PhD thesis, School of business, Kenyatta university.

- Messmer, M. (2006) 'Four keys to improved staff retention' Strategic Finance, 88 (4), 13.

- Miodonski, B. (2005) 'Re-recruit best employees to retain them', Contractor Magazine, 52 (9), 12.

- Mudor, H. \& Tooksoon, P. (2011) 'Conceptual framework on the relationship between human resource management practices, job satisfaction, and turnover', Journal of Economics and Behavioral Studies, 2(2), 41-49.

- Nadiri, H. \& Tanova, C. (2010) 'An investigation of the role of justice in turnover intentions, job satisfaction and organizational citizenship behavior in hospitality industry', International Journal of Hospitality Management, 29, 33-41.

- Nyberg, A. (2010) 'Retaining your high performers: Moderators of the performance-job satisfaction-voluntary turnover relationship', Journal of Applied Psychology, 95, 440-453.

- Pepe, M. (2010) 'The impact of extrinsic motivational dissatisfiers on employee level of job satisfaction and commitment resulting in the intent to turnover', Journal of Business\& Economics Research, 8 (9), 99-107.

- Philippe, W.T.; Helping, S. \& Koehler, J.W. (2009) 'Managerial communications that significantly affect employees' perception', Review of Business Research, 9 (4), 51-57.

- Poon, J. (2004) 'Effects of performance appraisal politics on job satisfaction and turnover intentions', Personal Review, 33 (3), 322-334.

- Preenen, P.; DePlater, I; VanVianen, A. \& Keijzer, L. (2011) 'Managing voluntary turnover through challenging assignments', Group\& Organization Management, 36 (3), 308-344.

- Rader, B. (2012) 'Non-monetary strategies to retain key employees', Master Thesis, William F. Harrah College of Hotel Administration, University of Nevada, Las Vegas.

- Ratna, R. \& Chawla, S. (2012) 'Key factors of retention strategies in telecom sector', Global Management Review, 6 (3), 35-46.

- Rathnaweera, R. R. (2010) 'Do HRM practices impact employee satisfaction, commitment or retention? : Empirical studies of Sri Lankan public sector banks', Master Thesis, Faculty of Economics and Social Sciences, University of Ager. 
- Raybould, M. \& Yam, L. (2011) 'Employee retention: Job embeddedness in the hospitality industry', 9th Asia Pacific Chire Conference, Polytechnic University, 1-6.

- Salas, E.; Cooke, N.J. \& Rosen, M.A. (2008) 'On teams, teamwork and team performance: Discoveries and developments', Hum. Factors, 50: 540-547 cited in Hussain and Sana ur Rehman (2013) 'Do Human Resource Management Practices Inspire Employees' Retention?', Research Journal of Applied Sciences, Engineering and Technology, 6(19), 3625-3633.

- Seibert, S.E., Silver, S.R. \& W.A. Randolph, W.A. (2004) 'Taking empowerment to the next level: A multiplelevel model of empowerment, performance and satisfaction', Academy Management Journal, 47(3), 332-349.

- Shriberg, A. (2009) 'Effectively leading and managing a virtual team', Business Review, 12 (2), 1-2.

- Spector, P. (1992). "Summated Rating Scale Construction: An Introduction", Sage Publications, Inc.

- Tracey, R. \& Hinkin, J.B. (2000) 'The cost of turnover: Putting a price on the learning curve', Cornell Hotel and Restaurant Administration Quarterly, 41 (3), 14-21.

- Tracey, R. \& Hinkin, J.B. (2008) 'Contextual factors and costs profiles associated with employee turnover', Cornell Hospitality Quarterly, 49, 12-27.

- Vasquez, D. (2014) 'Employee retention for economic stabilization: A qualitative phenomenological study in the hospitality sector', International Journal of Management, Economics and Social Sciences, 3 (1), 1-17.

- Wagar, T.H. \& Rondeau, K.V. (2006) 'Retaining employees in small and medium-sized firms: examining the link with human resource management', Journal of Applied Management and Entrepreneurship, 11 (2), 3-16.

- Woods, H.R.; Cho, S.; Jang, S. \& Erdem, M. (2006) 'Measuring the impact of human resource management practices on hospitality firms' performances', International Journal of Hospitality Management, 25, $262-277$.

- Wright, T.A. \& Bonett, D.G. (2007) 'Job satisfaction and psychological well-being as non additive predictors of workplace turnover', Journal of Management, 33, 141-160.

- Yang, T.J. (2010) 'Antecedents and consequences of job satisfaction in the hospitality industry', International Journal of Hospitality Management, 29, 609-619. 